\title{
Diagnostic challenges in celiac disease
}

\author{
Karol Kowalski $^{A-D, F}$, Agata Mulak ${ }^{A, C-F}$, Maria Jasińska ${ }^{B, C, F}$, Leszek Paradowski ${ }^{A, E, F}$ \\ Department of Gastroenterology and Hepatology, Wroclaw Medical University, Poland \\ A - research concept and design; $B$ - collection and/or assembly of data; $C$ - data analysis and interpretation; \\ $D$ - writing the article; $E$ - critical revision of the article; $F$ - final approval of article
}

\section{Address for correspondence \\ Agata Mulak}

E-mail:agata.mulak@wp.pl

\section{Funding sources}

None declared

\section{Conflict of interest}

None declared

Received on July 28, 2015

Revised on November 09, 2015

Accepted on March 31, 2016

DOI

10.17219/acem/62452

\section{Copyright}

Copyright by Author(s)

This is an article distributed under the terms of the

Creative Commons Attribution Non-Commercial License

(http://creativecommons.org/licenses/by-nc-nd/4.0/)

\begin{abstract}
Diagnosis of celiac disease in adults is currently based on serologic tests in combination with histopathological assessment of small intestinal biopsy specimens. High titers of celiac-specific antibodies in immunocompetent patients with villous atrophy in a good quality biopsy sample allow us to state a confident diagnosis. The relief of symptoms and histological improvement after embarking on a gluten free diet further support the initial diagnosis. However, in some cases, these conditions are not fulfilled, which requires a critical evaluation of laboratory and histopathology results and a consideration of other potential causes for the observed pathologies. To avoid diagnostic uncertainty, both biopsy and laboratory testing should be performed on a diet containing gluten. Immune deficiency, cross reaction of antibodies and possibilities of seronegative or latent celiac disease should be considered while evaluating serology results. Uneven distribution and variable intensity of histopathological changes in the small intestine along with multiple disorders presenting a similar specimen image may lead to invalid biopsy results. Additional laboratory testing and careful examination of a patient's history may deliver important data for a differential diagnosis and a more specific biopsy evaluation. Persistence or recurrence of symptoms, despite the ongoing treatment, requires a revision of the initial diagnosis, an evaluation of the gluten free diet and a search for concurrent disorders or complications.
\end{abstract}

Key words: celiac disease, villous atrophy, lymphocytic duodenosis, non-celiac enteropathy, non-responsive celiac disease 


\section{Introduction}

Celiac disease (CD) is a chronic small intestinal immune-mediated enteropathy triggered by the exposure to dietary gluten in genetically predisposed individuals. ${ }^{1}$ Diagnosis of CD is valid in patients who, while remaining on gluten containing diet, present positive serology and obvious celiac histopathology. These patients can readily initiate a gluten free diet (GFD). Strict adherence to a GFD in every case is important, as untreated CD may lead to severe complications, e.g. increased risk of malignancies, bone fractures or infertility. ${ }^{2}$ However, in some cases, laboratory and histological findings are inconsistent with symptoms presented by patients and are insufficient for straightforward diagnosis. Different factors can influence serology or histopathological results reducing their sensitivity and specificity. A variety of other disorders with similar symptoms and histopathology can mimic $C D$ and should be considered in the differential diagnosis. In these equivocal cases, a detailed investigation is required, using ancillary testing and different diagnostic approach.

\section{Serologic testing for celiac disease}

The preferred single test for detecting CD is IgA antitissue transglutaminase antibody (TTG IgA), which is characterized by high sensitivity (93\%) and specificity (95\%). ${ }^{3,4}$ Another commonly used test is IgA anti-endomysial antibody (EMA), which is the most specific of all assays. ${ }^{4}$ However, the latter test is technically more difficult, as it requires an immunofluorescence technique, which is a qualitative method; therefore, it is observer dependent and less objective. This makes EMA less time and cost efficient compared to ELISA based TTG test. ${ }^{4}$ Although these tests are both very effective, serology alone is not sufficient to confirm the diagnosis (at least in adult patients). ${ }^{4}$

\section{False positive results}

False positive results can occur due to a cross reaction of antibodies in such conditions as enteric infection, chronic liver disease, congestive heart failure or hypergammaglobulinemia. ${ }^{5}$

\section{False negative results}

The most important factor for reliable serology results is that the patient needs to be on gluten containing diet before testing, as being on a low-gluten diet is the main reason for false negative serology. ${ }^{5}$ False negative results may be associated with IgA deficiency, which is more common in CD patients than in the general population, since $2-3 \%$ of the patients are affected. ${ }^{3}$ To ensure all pa- tients with IgA deficiency are properly tested for CD it is recommended to either measure serum IgA level in all patients or include both IgA and IgG based testing. ${ }^{3,5}$ In IgA deficient patients, an IgG based test (anti-deamidatedgliadin peptide [DGP] IgG antibodies or TTG IgG antibodies) should be performed. ${ }^{3}$ The most effective combination of immunoassays is TTG IgA and DGP IgG. ${ }^{4}$

The antibody titers correspond with the degree of villous atrophy and in less destructive lesions are often lowlevel or negative. ${ }^{6-8}$ Therefore, negative serology does not exclude diagnosis and if suspicion of CD is high, intestinal biopsy should be performed even if serology is negative. $^{3}$

\section{Seronegative celiac disease}

Seronegative celiac disease (SNCD) is defined by the absence of TTG antibodies in the presence of a positive histopathology and antigen (HLA) haplotype DQ2 and/or DQ8. ${ }^{8}$ This condition may be caused by strong antigenantibody affinity resulting in mucosal deposition of tissue transglutaminase (tTG)/anti-tTG immuno-complexes and lack of passage of antibodies to circulation. ${ }^{8}$ Detection of these deposits in small intestinal biopsy strongly suggests CD. ${ }^{9}$ Another possible explanation might be an incomplete maturation of plasma cells with a consequent failure of antibodies production. ${ }^{8}$ Although SNCD is uncommon, it is responsible for $6-28 \%^{2,10}$ of seronegative villous atrophy and is, therefore, one of the main reasons for this condition. ${ }^{10}$

\section{Latent or potential celiac disease}

There are several reasons for positive serology without villous atrophy, a condition defined as latent or potential CD. ${ }^{1}$ In these patients mild histological changes, such as increased intraepithelial lymphocytes (IELs) can be present. ${ }^{11}$ Because lesion distribution in $\mathrm{CD}$ is often uneven, villous atrophy may be localized solely in duodenal bulb or distal parts of jejunum, thus missed by biopsy. Therefore, if this condition persists, repeated biopsy or capsule endoscopy might be necessary. ${ }^{2}$

\section{Histopathological changes in celiac disease}

The small intestinal mucosa is made up of villi which extend above the surface mucosa and the crypts of Lieberkühn, which extends below the surface. ${ }^{6}$ The normal villous to crypt ratio ranges from $3: 1$ to $5: 1 .^{12}$ The villous epithelium is composed primarily of absorptive cells and goblet cells, with IELs between them. These are mainly CD3+ and CD8+ T lymphocytes, usually distributed in decrescendo-like pattern with higher count at the basis of the villi and decreasing towards the tip. The normal IELs 
count is now considered as less than 25 per 100 enterocytes. ${ }^{13}$ Plasma cells, lymphocytes and little amount of eosinophils and macrophages are usually present in the lamina propria. ${ }^{6}$

\section{An approach to biopsy}

Small bowel biopsy is considered to be the gold standard for diagnosis of CD. ${ }^{5}$ Because histopathological changes related to $\mathrm{CD}$ are patchy, multiple biopsies of the duodenum, including one or two biopsies of the bulb and at least 4 biopsies of post-bulbar duodenum should be performed. ${ }^{3}$ Duodenal bulb is the first contact point of gluten and in $9-13 \%$ of patients may be the only location of villous atrophy. ${ }^{3,14,15}$ However, inflammatory changes of peptic injury and distortion of villi in areas overlying Brunner glands or lymphoid follicles may cause certain difficulties in interpretation of duodenal bulb specimens. $^{12,15}$

\section{Lymphocytic duodenosis}

Histological changes associated with CD can be classified according to Marsh/Oberhuber or Corazza classification (Table 1). ${ }^{3}$ Marsh I lesion, also known as lymphocytic duodenosis (LD), is characterized by normal villous architecture and > 25 IELs per 100 enterocytes. ${ }^{16}$ This is a common condition, with a prevalence of $5.4 \%$ in the general population. ${ }^{17}$ Revealing LD in duodenal biopsy with positive serology may represent $C D$, but further investigation is required to support the diagnosis. ${ }^{3}$

Different studies evaluated CD prevalence in $9 \%$ up to $40 \%$ of patients with LD. ${ }^{18}$ Common reasons for this pathology are also Helicobacter pylori and other gastrointes-

Table 1. Summary of histological classifications frequently used for celiac disease ${ }^{3}$

\begin{tabular}{|c|c|c|c|c|}
\hline \multirow{2}{*}{$\begin{array}{c}\text { Marsh modified } \\
\text { (Oberhuber) }\end{array}$} & \multicolumn{3}{|c|}{ Histologic Criterion } & \multirow{2}{*}{ Corazza } \\
\hline & $\begin{array}{l}\text { increased } \\
\text { intraepithelial } \\
\text { lymphocytes* }\end{array}$ & crypt hyperplasia & villous atrophy & \\
\hline Type 0 & no & no & no & none \\
\hline Type 1 & yes & no & no & \multirow{2}{*}{ grade $A$} \\
\hline Type 2 & yes & yes & no & \\
\hline Type 3a & yes & yes & yes (partial) & \multirow{2}{*}{ grade B1 } \\
\hline Type 3b & yes & yes & yes (subtotal) & \\
\hline Type 3c & yes & yes & yes (total) & grade $B 2$ \\
\hline
\end{tabular}

* > 40 intraepithelial lymphocytes per 100 enterocytes for Marsh modified (Oberhuber); > 25 intraepithelial lymphocytes per 100 enterocytes for Corazza. tinal infections, small intestinal bacterial overgrowth, use of nonsteroidal anti-inflammatory drugs or proton pump inhibitors, hypogammaglobulinemia, autoimmune or chronic inflammatory disorders. In most cases no cause for LD is found and these changes usually disappear on repeated biopsy. ${ }^{6,16,18,19}$ There is a high prevalence of patients fulfilling irritable bowel syndrome (IBS) criteria in this group. ${ }^{16}$ In fact, the association between IBS and LD has been reported in several studies, where immunocytochemical staining for $\mathrm{T}$ cells (CD3) was performed. ${ }^{16,19-21}$ However, in the study in which standard haematoxylin and eosin (H\&E) staining was used none of the investigated samples exceeded 25 IELs per 100 enterocytes. ${ }^{22}$

\section{Borderline cases}

As mentioned above, serology correlates with degree of mucosal injury; therefore, negative serology does not exclude CD in patients with LD. ${ }^{16,18}$ In equivocal cases, the patient's history should be revisited. If there is no apparent cause of LD and CD is suspected, HLA typing and repeated biopsy after gluten challenge should be performed. ${ }^{16}$ Recent study shows that intake of $\geq 3 \mathrm{~g}$ of gluten a day (amount equal to 1.5 slices of bread) will induce histopathological findings consistent with celiac disease in approximately $90 \%$ of patients after 14 day trial. ${ }^{23}$ Extending the challenge for another 6 weeks in patients who tolerate the challenge well may further improve diagnostic sensitivity. If repeated biopsy and serology after gluten challenge are negative, $C D$ is unlikely. Final follow-up serologic test is performed after 6-12 months of gluten containing diet. ${ }^{23}$ Another approach, where initial response to a GFD is assessed seems less accurate, as $38 \%$ of patients with LD who improve on a GFD are HLA DQ2/DQ8 negative. ${ }^{16}$

\section{Non-celiac gluten sensitivity}

In the case of negative testing for $\mathrm{CD}$ and wheat allergy (WA), nonceliac gluten sensitivity (NCGS) should be considered. This condition may also reveal mildly inflamed mucosa, although IELs count is not as high as in patients with CD. Typically, symptoms disappear after gluten elimination. An open gluten challenge (monitored reintroduction of gluten containing food) or preferably double blinded gluten challenge is performed after at least 3 weeks on a GFD. Relapse of symptoms, with onset hours to days after gluten exposure, confirms the diagnosis. ${ }^{24,25}$ 


\section{Villous atrophy}

Definite diagnosis of CD in adults is made in the presence of villous atrophy (VA) in duodenal biopsy. ${ }^{2}$ VA is defined as flattening of surface secondary to the shortening and blunting of the intestinal villi and is associated with an increase in crypt cell mitoses and crypt elongation. ${ }^{12}$ To correctly assess VA in duodenal biopsy, good quality samples, properly oriented by qualified technician are essential., ${ }^{2,12}$ Tangential sectioning and insufficient size of samples may lead to misinterpretation and overdiagnosis of VA. ${ }^{26}$ Although CD is the most common cause of villous atrophy, there are many other conditions with similar histopathology. ${ }^{27}$ Therefore, in the absence of positive serology, this condition, defined as seronegative villous atrophy (SVA), should be further investigated. Performing HLA DQ2/DQ8 typing in the first step can exclude CD in case of negative result. Careful review of the patient's history may deliver clinical clues to narrow down the possible causes. Additional testing for parasites, bacterial or viral infections, anti-enterocyte antibodies or serum immunoglobulin level is suggested. Finally, biopsy specimens should by reviewed by experienced gastrointestinal pathologists in search for specific histological features (Table 2). ${ }^{10,28}$ In previously conducted research, definitive etiology for VA was found in $85 \%$ of patients, of which most common were seronegative celiac disease, medication related villous atrophy, common variable immunodeficiency (CVID), autoimmune enteropathy, giardia infection and lymphoma. ${ }^{10}$ Immune mediated enteropathy, differently called unclassified sprue, was a diagnosis of exclusion. ${ }^{10}$

\section{Uncertain cases management}

As mentioned above, in patients remaining on a gluten containing diet, positive serology and obvious celiac histopathology is sufficient to confidently state diagnosis of CD and introduce a GFD. In equivocal cases, further investigations should be performed to exclude other potential causes for present pathologies (Table 3). If CD remains possible, these patients should embark on a GFD. ${ }^{15}$ Histological changes in response to a GFD in patients with VA strongly support diagnosis. ${ }^{3}$ In contrast to previous recommendations, follow-up biopsy should not be performed before 6 months on a GFD as in this period a complete recovery of duodenal mucosa is infrequently achieved. ${ }^{29}$ In questionable cases, gluten challenge after at least 2 years on a GFD can be performed to support the diagnosis (Fig. 1). ${ }^{9}$

Symptomatic improvement on a GFD or exacerbation after gluten challenge has very low positive predictive value and should not be used as diagnostic criteria. ${ }^{3,9}$

Fig. 1. Diagnostic algorithm for celiac disease

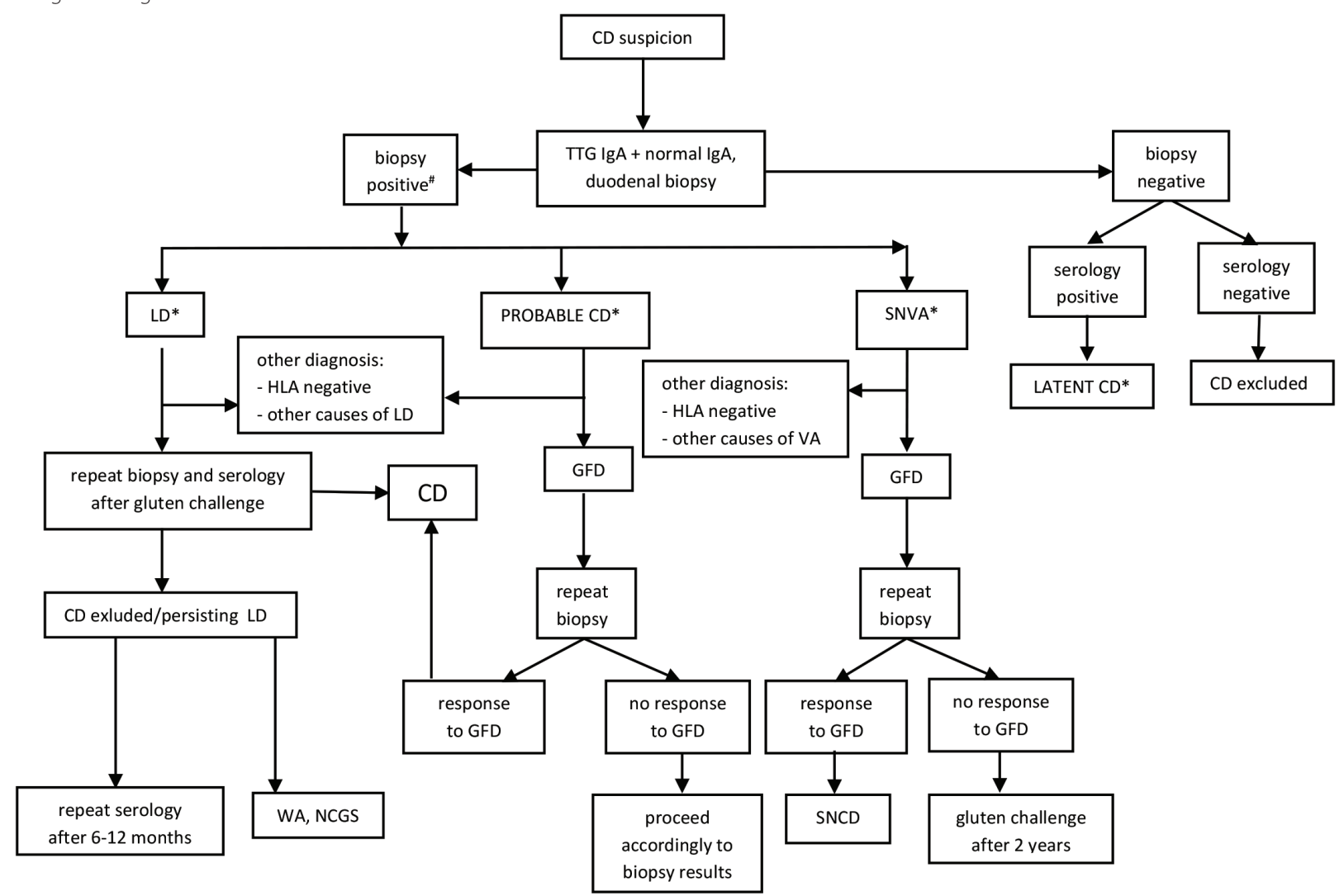

CD - celiac disease; GFD - gluten free diet; LD- lymphocytic duodenosis; SNVA - seronegative CD; \# - normal architecture and increased intraepithelial lymphocytes (IELs) ( $\geq 25 / 100$ enterocytes) or villous atrophy +/- increased IELs; ${ }^{*}$ definitions and management in Table 3. 
Table 2. Histological mimics of CD in seronegative patients with normal architecture and increased intraepithelial lymphocytes (IELs) ( $\geq 25 / 100$ enterocytes) or villous atrophy $+/$ - increased IELs

\begin{tabular}{|c|c|c|c|}
\hline Suspected etiology & Villous morfology & Other histological findings & Clues \\
\hline \multicolumn{4}{|c|}{ Drugs } \\
\hline Medication related & $\begin{array}{l}\text { increased IELs (PPIs) +/- VA } \\
\text { (e.g.azathioprin, colchicine, } \\
\text { ipilimumab, mycophenolate, } \\
\text { NSAIDs, olmesartan }{ }^{32} \\
\text { telmisartan }^{33} \text {, methotrexate } \\
\text { (10) }\end{array}$ & $\begin{array}{l}\text { prominent neutrophilic } \\
\text { inflammation (NSAIDs) }{ }^{34}, \\
\text { +/- increased subepithelial } \\
\text { collagen (olmesartan) })^{32}\end{array}$ & improvement after drug discontinuation \\
\hline \multicolumn{4}{|c|}{ Infections } \\
\hline $\begin{array}{l}\text { Helicobacter pylori (HP) } \\
\text { gastritis }\end{array}$ & $\begin{array}{l}\text { increased IELs in an architecturally } \\
\text { normal duodenal mucosa }\end{array}$ & - & improvement after HP eradication ${ }^{35}$ \\
\hline Giardia lamblia infection & $\begin{array}{l}\text { usually normal mucosa, variable } \\
\text { VA in a minority of cases } \\
\text { IELs not markedly increased }\end{array}$ & $\begin{array}{l}\text { trophozoites on the surface of villi, } \\
\text { reactive lymphoid follicles }{ }^{36}\end{array}$ & $\begin{array}{l}\text { positive stool for parasites and ova exam } \\
\text { ( } 2-3 \text { samples) and/or antigen detection }{ }^{37}\end{array}$ \\
\hline Post viral enteropathy & $\begin{array}{l}\text { diffuse, moderate to marked VA with } \\
\text { increased IELs }{ }^{32}\end{array}$ & increased crypt mitoses ${ }^{12}$ & $\begin{array}{l}\text { acute, self-limiting illness }{ }^{28} \text {, anti-gliadin } \\
\text { antibodies may be slightly increased }{ }^{12}\end{array}$ \\
\hline $\begin{array}{l}\text { Small intestinal bacterial } \\
\text { overgrowth }\end{array}$ & $\begin{array}{l}\text { normal to moderate blunting of villi, } \\
\text { may have an increased number of } \\
\text { IELs and/or neutrophils }\end{array}$ & $\begin{array}{l}\text { normal to increased number of } \\
\text { plasma cells in lamina propria }{ }^{38}\end{array}$ & $\begin{array}{l}\text { positive hydrogen breath test, positive } \\
\text { duodenal aspirate }\end{array}$ \\
\hline AIDS enteropathy & $\begin{array}{l}\text { normal villous architecture } \\
\text { to partial VA }\end{array}$ & $\begin{array}{l}\text { depletion in mucosal CD } 4 \mathrm{~T} \\
\text { lymphocytes, increase in CD8 } \\
\text { lymphocyte count, increased crypt } \\
\text { depth with normal mitoses per } \\
\text { crypt }^{12}\end{array}$ & $\begin{array}{l}\text { opportunistic infections, such as } \\
\text { microsporidiosis, cyclosporidiosis, } \\
\text { leishmaniosis, isosporiasis, } \\
\text { cryptosporidiosis, mycobacterial or CMV } \\
\text { infections may be present }{ }^{12}\end{array}$ \\
\hline Whipple's disease & $\begin{array}{l}\text { shortened, blunted villi, } \\
\text { increased IELs }\end{array}$ & $\begin{array}{l}\text { infiltration of foamy macrophages } \\
\text { into lamina propria that contain } \\
\text { intracellular PAS positive granules, } \\
\text { bacterial rods within macrophages, } \\
\text { plasma cells or in extracellular } \\
\text { space }^{34}\end{array}$ & $\begin{array}{l}\text { other clinical findings include } \\
\text { arthropathies, lymphadenopathy, fever, } \\
\text { and hyperpigmentation of sun-exposed } \\
\text { skin, cardiovascular and neurologic } \\
\text { pathologies }\end{array}$ \\
\hline Tropical sprue & $\begin{array}{l}\text { mild to moderate blunting of villi, } \\
\text { increased IELs }{ }^{38} \text { total VA is rare }{ }^{32}\end{array}$ & $\begin{array}{l}\text { changes are equally prominent in } \\
\text { the jejunum and ileum in addition } \\
\text { to the duodenum } 32 \text {, increased } \\
\text { numbers of plasma cells and } \\
\text { eosinophils in lamina propria }{ }^{38}\end{array}$ & $\begin{array}{l}\text { travel to endemic areas (Central and } \\
\text { South America and South and Southeast } \\
\text { Asia), } B_{12} \text { and folate deficiencies, } \\
\text { megaloblastic anemia, atrophic glossitis, } \\
\text { megaloblastic cytological changes, } \\
\text { response to antibiotics }\end{array}$ \\
\hline \multicolumn{4}{|c|}{ Autoimmune disease } \\
\hline $\begin{array}{l}\text { Autoimmune } \\
\text { enteropathy }\end{array}$ & $\begin{array}{l}\text { usually flat villi, may have slightly } \\
\text { increased number of IELs, usually has } \\
\text { cryptitis (neutrophils) }{ }^{38}\end{array}$ & $\begin{array}{l}\text { GVHD-like apoptosis with } \\
\text { lymphocytes infiltrating crypt bases, } \\
\text { lack of goblet cells, endocrine cells } \\
\text { and Paneth cells if anti-goblet cell } \\
\text { antibodies present }{ }^{38}\end{array}$ & $\begin{array}{l}\text { history of autoimmune conditions }{ }^{28} \text {, } \\
\text { lack of any triggering food protein }{ }^{12}, \\
\text { presence of anti-enterocyte antibodies, } \\
\text { anti-goblet cell antibodies, anti- } \\
\text { parietal cell antibodies }{ }^{38} \text {, anti-gliadin } \\
\text { antibodies may be present }{ }^{12} \text {, associated } \\
\text { with immunodeficiency states and } \\
\text { thymomas }^{38}\end{array}$ \\
\hline $\begin{array}{l}\text { Extraintestinal } \\
\text { autoimmune disorders }\end{array}$ & $\begin{array}{l}\text { increased number of IELs and variable } \\
\text { degree of VA }{ }^{32}\end{array}$ & - & $\begin{array}{l}\text { Hashimoto thyroiditis, Graves' } \\
\text { disease, rheumatoid arthritis, lupus } \\
\text { erythomatosus, multiple sclerosis, } \\
\text { psoriasis, ankylosing spondylitis } \\
\text { or progressive systemic sclerosis, } \\
\text { type } 1 \text { diabetes }\end{array}$ \\
\hline
\end{tabular}

CD - celiac disease; VA - villous atrophy; IELs - intraepithelial lymphocytes; PPIs - proton pump inhibitors; NSAIDs - nonsteroidal anti-inflammatory drugs; ESR - erythrocyte sedimentation rate; ASCA - anti-Saccharomyces cerevisiae antibodies; CMSE - cow's milk protein sensitive enteropathy. 
Table 2. Histological mimics of CD in seronegative patients with normal architecture and increased intraepithelial lymphocytes (IELs) ( $\geq 25 / 100$ enterocytes) or villous atrophy +/- increased IELs (cont.)

\begin{tabular}{|c|c|c|c|}
\hline Suspected etiology & Villous morfology & Other histological findings & Clues \\
\hline \multicolumn{4}{|c|}{ Immune disorders } \\
\hline $\begin{array}{l}\text { Common variable } \\
\text { immunodeficiency }\end{array}$ & $\begin{array}{l}\text { variable degree of } \mathrm{VA}+/ \text { - increased } \\
\mathrm{IELs}{ }^{40}\end{array}$ & $\begin{array}{l}\text { nodular lymphoid hyperplasia, } \\
\text { absence of plasma cells }{ }^{41} \text {, } \\
\text { polymorphonuclear infiltrate, graft- } \\
\text { versus-host disease-like lesions }{ }^{42}\end{array}$ & $\begin{array}{l}\text { fulfilled diagnostic criteria: } \\
\text { hypogammaglobulinaemia (lgG below } \\
5 \mathrm{~g} / \mathrm{L} \text { ), no other cause identified for } \\
\text { immune defect, recurrent, severe or } \\
\text { unusual infections, poor response to } \\
\text { vaccination }{ }^{41} \text {, may coexist with } \\
\text { G. lamblia infection or celiac disease }\end{array}$ \\
\hline
\end{tabular}

Neoplasia

Enteropathy-type

intestinal T cell

lymphoma (EITCL) /

enteropathy associated

T-cell lymphoma (EATL)

Immunoproliferative

small intestinal disease

(IPSID)
VA, distorted architecture, ulcerations ${ }^{12}$ clonal proliferation of phenotypically, abnormal intraepithelial lymphocytes (IELs) ${ }^{43}$ neoplastic lymphocytes, nonspecific mononuclear infiltrate in lamina propria, the adjacent intact mucosa shows the histological features of $C D^{12}$ signs of obstruction, perforation or haemorrhage, a palpable tumour may be found ${ }^{12}$

thickening, erythema and nodularity of the mucosal folds may be seen in the duodenum and upper jejunum ${ }^{12}$, affects mainly older children and young adults; obstruction and abdominal masses are typical for the advanced stage presence of anomalous a heavy chain protein in the serum ( $20 \%$ to $90 \%$ of patients) common parasitic infestations ${ }^{44}$ plasma cells and centrocyte-like lymphocytes in the lamina propria $^{12}$

\section{Other}

\begin{tabular}{|c|c|c|c|}
\hline Peptic duodenitis & $\begin{array}{l}\text { normal IELL }{ }^{12} \text {, variable } V A^{32} \text {, may be } \\
\text { associated with VA of the mucosa of } \\
\text { the distal duodenum } \\
32\end{array}$ & $\begin{array}{l}\text { prominent neutrophilic } \\
\text { inflammation }{ }^{32} \text {, extensive gastric } \\
\text { metaplasia and Brunner's gland } \\
\text { hyperplasia }{ }^{34} \text {, oedema, acute } \\
\text { inflammation in the lamina propria } \\
\text { and epithelium, erosions }{ }^{32}\end{array}$ & $\begin{array}{l}\text { peptic ulcer disease or improvement with } \\
\text { acid suppressive therapy }{ }^{28}\end{array}$ \\
\hline Crohn's disease & $\begin{array}{l}\text { normal }^{12} / \text { increased IELs, variable } \\
\text { degree of architectural distortion }{ }^{32}\end{array}$ & $\begin{array}{l}\text { focal acute inflammation } \\
\text { (cluster of neutrophils) flanked } \\
\text { by almost normal appearing } \\
\text { mucosa +/-granulomas }{ }^{12} \text {, apthous } \\
\text { ulceration, fissure formation., } \\
\text { pyloric metaplasia, fibrosis } \\
\text { lymphoplasmacytosis }{ }^{32}\end{array}$ & $\begin{array}{l}\text { elevated ESR/ASCA, multilevel } \\
\text { involvement of the intestine }{ }^{28}\end{array}$ \\
\hline $\begin{array}{l}\text { Eosinophilic } \\
\text { gastroenteritis }\end{array}$ & variably perturbed architecture ${ }^{12}$ & $\begin{array}{l}\text { eosinophilic infiltration of small } \\
\text { bowel mucosa }{ }^{28}\end{array}$ & $\begin{array}{l}\text { elevated peripheral eosinophil count, } \\
\text { no evidence of parasitic, intestinal or } \\
\text { extraintestinal disease }^{12} \text {, } \\
\text { multiple allergies }^{28}\end{array}$ \\
\hline Food allergies & $\begin{array}{l}\text { increased IELs sometimes minimal } \\
\text { architecture distortion, partial VA } \\
(\text { CMSE) }\end{array}$ & $\begin{array}{l}\text { lymphonodular hyperplasia, lesions } \\
\text { most prominent in duodenal } \\
\text { bulb, may extend to all parts of } \\
\text { gastrointestinal tract (CMSE) }\end{array}$ & $\begin{array}{l}\text { multiple allergies, atopy, serum lgE allergy } \\
\text { testing }{ }^{28}\end{array}$ \\
\hline Collagenous sprue & "flat" biopsy appearance 45 & subepithelial collagen deposits²8 & $\begin{array}{l}\text { collagen deposits may also be present } \\
\text { in the colon (i.e. collagenous colitis) } \\
\text { or stomach (i.e. collagenous gastritis), } \\
\text { positive endomysial antibodies }{ }^{45}\end{array}$ \\
\hline
\end{tabular}

CD - celiac disease; VA - villous atrophy; IELs - intraepithelial lymphocytes; PPIs - proton pump inhibitors; NSAIDs - nonsteroidal anti-inflammatory drugs; ESR - erythrocyte sedimentation rate; ASCA - anti-Saccharomyces cerevisiae antibodies; CMSE - cow's milk protein sensitive enteropathy. 
Table 3. Suggested diagnostic path in symptomatic patients diagnosed for celiac disease (CD) with equivocal results

\begin{tabular}{|c|c|c|c|}
\hline Results & Diagnosis & Further investigations & Possible cause \\
\hline sero +, VA -, IELs + & probable $C D^{2}$ & $\begin{array}{l}\text { consider other causes of LD*, HLA typing, } \\
\text { trial with GFD }\end{array}$ & $\begin{array}{l}\text { lesions in different part of small } \\
\text { intestine, other causes of LD* }\end{array}$ \\
\hline sero -, VA +, IELs +/- & seronegative VA & $\begin{array}{l}\text { consider other causes of VA*, HLA typing, } \\
\text { asses gluten ingestion, trial with GFD }\end{array}$ & $\begin{array}{l}\text { false negative serology, poor quality } \\
\text { biopsy sample, SNCD, nonceliac } \\
\text { villous atrophy* }\end{array}$ \\
\hline sero -, VA -, IELs + & lymphocytic duodenosis (LD) & $\begin{array}{l}\text { consider other causes of LD*, perform gluten } \\
\text { challenge, HLA typing, exclude WA (specific prick } \\
\text { test, wheat specific serum lgE), consider NCGS } \\
\text { (gluten challenge after GFD) }\end{array}$ & NCGS, WA, other causes of LD* \\
\hline sero +, VA -, IELs - ${ }^{\#}$ & latent/potential CD & $\begin{array}{l}\text { maintain on GCD, HLA typing, repeat biopsy and } \\
\text { serology, perform capsule endoscopy and/or } \\
\text { enteroscopy }\end{array}$ & $\begin{array}{l}\text { lesions in different part of small } \\
\text { intestine, false positive serology }\end{array}$ \\
\hline
\end{tabular}

CD - celiac disease; sero - serology; VA - villous atrophy; IELs - intraepithelial lymphocytes; WA - wheat allergy; NGCS - non-celiac gluten sensivity; SNCD - seronegative celiac disease; HLA - human leukocyte antigen; GCD - gluten containing diet; * other causes of LD/VA in Table 2; \# may present increased IELs according to some sources. ${ }^{10}$

Fig. 2. Management of non-responsive celiac disease

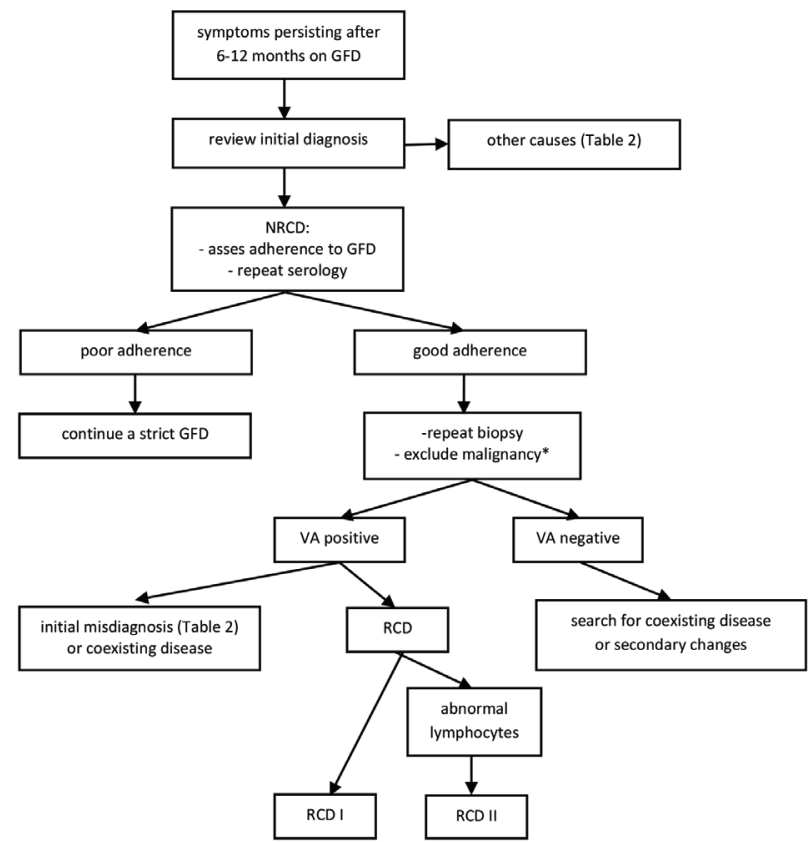

GFD - gluten free diet; NRCD - non-responsive celiac disease; VA - villous atrophy; RCD (l; II) - refractory celiac disease (type l; ll); *perform endoscopic or imaging procedures; such as magnetic resonance imaging (MRI); computed tomography (CT); enterography; double or single balloon enteroscopy; positive emission tomography (PET). ${ }^{27}$

\section{Non-responsive celiac disease}

Typically, in CD patients there is a substantial clinical and serological improvement after weeks or months on a GFD. ${ }^{30}$ However, as much as $4-30 \%$ of patients have persistent symptoms, signs, or laboratory abnormalities in spite of 6-12 months of treatment. ${ }^{2,3}$ These patients may be affected by non-responsive celiac disease (NRCD) and should be further diagnosed to find its cause.
The first step is confirmation of CD diagnosis by reviewing patient's initial biopsy and serology. If diagnosis is confident, then adherence do a GFD should be evaluated. Gluten ingestion is the most common cause of NRCD and is responsible for $36-51 \%$ of cases. ${ }^{30}$ There is no objective laboratory method to detect gluten contamination. ${ }^{31}$ Although positive CD serology often indicates gluten exposure, 19-30\% of patients present positive serology despite complete gluten exclusion. ${ }^{30}$ Moreover, negative serology may not reveal intermittent or low-level gluten intake. ${ }^{3}$ Therefore, a detailed examination of the patient's diet by an expert dietitian in search for potential gluten sources is necessary. ${ }^{2,3}$ The next step is to repeat the small intestinal biopsy with colonic biopsies in the case of persistent diarrhea. ${ }^{3}$ If there is no villous atrophy, other conditions responsible for persisting symptoms should be considered. ${ }^{3}$ One scenario is that primarily asymptomatic CD coexist with other disease that have similar symptoms but no evident villous atrophy, e.g. food intolerances, small intestinal bacterial overgrowth, microscopic colitis, eosinophilic enteritis, IBS, Crohn's disease, bile salt malabsorption, hyperthyroidism. ${ }^{2,3,31}$ Another option is that secondary changes, such as lactose intolerance or pancreatic exocrine deficiency persist despite villous recovery. ${ }^{31}$

The presence of VA on repeated biopsy may result either from initial misdiagnosis (Table 2), concurrent autoimmune disease that does not respond to a GFD or refractory celiac disease (RCD). ${ }^{3,31}$ Endoscopic and imaging procedures should be employed to exclude malignancy as a cause of recurrent symptoms, particularly in patients presenting significant unexplained weight loss, bowel obstruction, gastrointestinal bleeding, anorexia, pruritus, fever, nocturnal diaphoresis or abdominal pain. ${ }^{30}$ Finally, RCD remains diagnosis of exclusion (Fig. 2). 


\section{Refractory celiac disease}

RCD is defined as persistent or recurrent malabsorption symptoms and signs with VA despite a strict GFD for more than 12 months. ${ }^{1}$ This condition affects approximately $1-2 \%$ of $C D$ patients and is responsible for $10-18 \%$ of NRCD cases. ${ }^{15,30}$ It is typically diagnosed at the age of 50 years onwards and is exceptional in childhood. ${ }^{30,31}$ The majority of patients present recurrent symptoms years after initial clinical response to a GFD (secondary RCD). Primary RCD is less common and relates to a subset of patients that initially fail to respond to a GFD. ${ }^{30}$ Identifying abnormalities in IELs differentiate between 2 subcategories of RCD. Loss of CD 3 or CD 8 surface markers detected by immunohistochemistry or flow cytometry, as well as T-cell receptor chains clonal rearrangement indicated by molecular methods are characteristic for RCD type II. ${ }^{3,30}$ These patients have poorer prognosis in relation to RCD type I patients, because of a much more frequent transformation into enteropathyassociated T-cell lymphoma (EATL). ${ }^{30}$

\section{Conclusions}

In summary, although $C D$ diagnosis is usually based on typical symptoms and consistent laboratory and histological findings, there are unclear cases in which more detailed examination is required. Each diagnostic method is susceptible to different factors influencing its outcome, which should be considered while assessing the results. Careful and accurate diagnostic approach reduces the risk of misdiagnosis. Specific histopathological image in combination with clinical clues help to differentiate CD from its mimics and allow for correct treatment. Persistence or recurrence of symptoms despite ongoing treatment requires revision of initial diagnosis, evaluation of adherence to a GFD and searching for concurrent disorders or complications.

\section{References}

1. Ludvigsson JF, Leffler DA, Bai JC, et al. The Oslo definitions for coeliac disease and related terms. Gut. 2013;62:43-52.

2. Ludvigsson JF, Bai JC, Biagi $F$, et al. Diagnosis and management of adult coeliac disease: Guidelines from the British Society of Gastroenterology. Gut. 2014;63:1210-1228.

3. Rubio-Tapia A, Hill ID, Kelly CP, Calderwood AH, Murray JA. American College of Gastroenterology clinical guidelines: Diagnosis and management of celiac disease. Am J Gastroenterol. 2013;108:656-676.

4. Schyum AC, Rumessen JJ. Serological testing for celiac disease in adults. United European Gastroenterol J. 2013;1:319-325.

5. Castillo NE, Theethira TG, Leffler DA. The present and the future in the diagnosis and management of celiac disease. Gastroenterol Rep. 2015;3:3-11.

6. Hammer S, Greenson J. The Clinical Significance of Duodenal Lymphocytosis With Normal Villus Architecture. Arch Pathol Lab Med. 2013;137:1216-1219.

7. Tursi A, Brandimarte G, Giorgetti GM. Prevalence of anti-tissue transglutaminase antibodies in different degrees of intestinal damage in celiac disease. J Clin Gastroenterol. 2003;36:219-221.
8. lerardi E, Losurdo G, Piscitelli D, et al. Seronegative celiac disease: Where is the specific setting? Gastroenterol Hepatol Bed Bench. 2015;8:110-116

9. Catassi C, Fasano A. Celiac disease diagnosis: Simple rules are better than complicated algorithms. Am J Gastroenterol. 2010;123:691-693.

10. DeGaetani M, Tennyson CA, Lebwohl B, et al. Villous atrophy and negative celiac serology: A diagnostic and therapeutic dilemma. Am J Gastroenterol. 2013;108:647-653.

11. Bao F, Green PH, Bhagat G. An update on celiac disease histopathology and the road ahead. Arch Pathol Lab Med. 2012;136: 735-745.

12. Serra S, Jani PA. An approach to duodenal biopsies. J Clin Pathol. 2006;59:1133-1150.

13. Veress B, Franzén L, Bodin L, Borch K. Duodenal intraepithelial lymphocyte-count revisited. Scand J Gastroenterol. 2004;39:138-144.

14. Evans KE, Aziz I, Cross SS, et al. A prospective study of duodenal bulb biopsy in newly diagnosed and established adult celiac disease. Am J Gastroenterol. 2011;106:1837-1742.

15. Walker MM, Murray JA. An update in the diagnosis of coeliac disease. Histopathology. 2011;59:166-179.

16. Aziz I, Evans KE, Hopper AD, Smillie DM, Sanders DS. A prospective study into theaetiology of lymphocytic duodenosis. Aliment Pharmacol Ther. 2010;32:1392-1397.

17. Walker MM, Murray JA, Ronkainen J, et al. Detection of celiac disease and lymphocytic enteropathy by parallel serology and histopathology in a population-based study. Gastroenterology. 2010;139:112-119.

18. Brown I, Mino-Kenudson M, Deshpande V, Lauwers G. Intraepithelial lymphocytosis in architecturally preserved proximal small intestinal mucosa: An increasing diagnostic problem with a wide differential diagnosis. Arch Pathol Lab Med. 2006;130:1020-1025.

19. VandeVoort JL, Murray JA, Lahr BD, et al. Lymphocytic duodenosis and the spectrum of celiac disease. Am J Gastroenterol. 2009;104:142-148.

20. Törnblom H, Lindberg G, Nyberg B, Veress B. Full-thickness biopsy of the jejunum reveals inflammation and enteric neuropathy in irritable bowel syndrome. Gastroenterology. 2002;123:1972-1979.

21. Wahnschaffe U, Ullrich R, Riecken EO, Schulzke JD. Celiac diseaselike abnormalities in a subgroup of patients with irritable bowel syndrome. Gastroenterology. 2001;121:1329-1338.

22. Walker MM, Talley NJ, Prabhakar M, et al. Duodenal mastocytosis, eosinophilia and intraepithelial lymphocytosis as possible disease markers in the irritable bowel syndrome and functional dyspepsia. Aliment Pharmacol Ther. 2009;29:765-773.

23. Leffler D, Schuppan D, Pallav K, et al. Kinetics of the histological, serological and symptomatic responses to gluten challenge in adults with coeliac disease. Gut. 2013;62:996-1004.

24. Catassi C, Bai JC, Bonaz B, et al. Non-Celiac Gluten Sensitivity: The New Frontier of Gluten Related Disorders. Nutrients. 2013;5:38393853.

25. Sapone A, Bai JC, Ciacci C, et al. Spectrum of gluten-related disorders: consensus on new nomenclature and classification. BMCMedicine. 2012;10:13.

26. Shidrawi RG, Przemioslo R, Davies DR, Tighe MR, Ciclitira PJ. Pitfalls in diagnosing coeliac disease. J Clin Pathology. 1994;47:693-694.

27. Ludvigsson JF, Brandt L, Montgomery SM, Granath F, Ekbom A. Validation study of villous atrophy and small intestinal inflammation in Swedish biopsy registers. BMC Gastroenterology. 2009;9:19.

28. Pallav K, Leffler DA, Tariq S, et al. Noncoeliacenteropathy: The differential diagnosis ofvillous atrophy in contemporary clinical practice. Aliment Pharmacol Ther. 2012;35:380-390.

29. Hutchinson JM, West NP, Robins GG, Howdle PD. Long-term histological follow-up of people with coeliac disease in a UK teaching hospital. QJM. 2010;103:511-517.

30. Rubio-Tapia A, Murray JA. Classification and management of refractory celiac disease. Gut. 2010;59:547-557.

31. Woodward J. The management of refractory coeliac disease. Ther Adv Chronic Dis. 2013;4;77-90.

32. Švajdler M, Daum O, Rychlý B: Diagnosing Celiac Disease: Role of the Pathologists. International Journal of Celiac Disease. 2014; 2:70-75. 
33. Cyrany J, Vasatko, T, Machac J, Nova M, Szanyi J, Kopacova M Telmisartan-associated enteropathy - is there any class effect? Aliment Pharmacol Ther. 2014; 40:569-570.

34. Babbin BA, Crawford K, Sitaraman SV. Malabsorption work-up: Utility of small bowel biopsy. Clin Gastroenterol Hepatol. 2006;4:1193-1198.

35. Nahon S, Patey-Mariaud De Serre N, et al. Duodenal intraepithelial lymphocytosis during Helicobacter pylori infection is reduced by antibiotic treatment. Histopathology. 2006;48:417-423.

36. Oberhuber G, Stolte M. Giardiasis: Analysis of histological changes in biopsy specimens of 80 patients. J Clin Pathol. 1990;43:641-643.

37. Gardner TB, Hill DR. Treatment of giardiasis. Clin Microbiol Rev. 2001;14:114-128.

38. Greenson JK. The biopsy pathology of non-coeliac enteropathy. Histopathology. 2015;66:29-36.

39. Muir-Padilla J, Myers J. Whipple disease: A Case report and review of the literature. Arch Pathol Lab Med. 2005;129: 933-936.

40. Teahon K, Webster AD, Price AB, Weston J, Bjarnason I. Studies on the enteropathy associated with primary hypogammaglobulinaemia. Gut. 1994;35:1244-1249.

41. Ameratunga R, Woon ST, Gillis D, Koopmans W, Steele R. New diagnostic criteriafor common variable immune deficiency (CVID), which may assist with decisions to treat with intravenous or subcutaneous immunoglobulin. Clin Exp Immunol. 2013;174:203-211.

42. Biagi F, Bianchi PI, Zilli A, et al. The significance of duodenal mucosal atrophy inpatients with common variable immunodeficiency: A clinical and histopathologic study. Am J Clin Pathol. 2012;138:185-189.

43. Halfdanarson TR, Litzow MR, Murray JA. Hematologic manifestations of celiac disease. Blood. 2007;109:412-421.

44. Al-Saleem T, Al-Mondhiry $\mathrm{H}$. Immunoproliferative small intestinal disease(IPSID): A model for mature B-cell neoplasms. Blood. 2005;105:2274-2280.

45. Freeman HJ. Update on collagenous sprue. World J Gastroenterol. 2010;16:296-298. 